\title{
LOW LEVEL OF GENETIC VARIATION WITHIN MELICA TRANSSILVANICA POPULATIONS FROM THE KRAKÓW-CZESTOCHOWA UPLAND AND THE PIENINY MTS REVEALED BY AFLPs ANALYSIS
}

\author{
Magdalena SZCZEPANIAK, ElŻBIETA CIEŚLAK \\ W. Szafer Institute of Botany, Polish Academy of Sciences, \\ Department of Vascular Plants Systematics \\ Lubicz 42, 31-512 Kraków, Poland \\ e-mail: Magdalena.Szczepaniak@ib-pan.krakow.pl
}

(Received: September 25, 2006. Accepted: April 3, 2007)

\begin{abstract}
Fragmented distribution, the breeding system and effects of genetic drift in small-size populations occurring at edge of the species' range play an important role in shaping genetic diversity of such a species. Melica transsilvanica is a plant rare in the flora of Poland, where it reaches the northern limit of its continuous range. Amplified Fragment Length Polymorphism (AFLP) DNA profiling method was applied to measure genetic diversity among and within populations of $M$. transsilvanica. Additionally, genetic relationships between $M$. transsilvanica and Melica ciliata, two closely related species, were explored. A total of 68 plants from 7 populations of M. transsilvanica and 24 plants from 2 populations of M. ciliata, collected in Poland and outside it, were analyzed. Using 294 AFLP fragments from 3 primer combinations, accessions were grouped into two major clusters associating with $M$. ciliata and $M$. transsilvanica, respectively. Further, two subclusters, corresponding to the samples collected from the Pieniny Mts and from the Kraków-Częstochowa Upland were clearly distinguished within the M. transsilvanica group. The hierarchical AMOVA exhibited significant genetic distinction between these geographic regions $(60.89 \%, p<0.001)$. The obtained results showed that the most genetic diversity resided between the populations of $M$. transsilvanica $(86.03 \%)$ while considerably lower genetic variation was found within the populations (13.97\%), which is consistent with the results reported for self-plants. The low level of AFLP genetic variation of $M$. transsilvanica can be caused by the geographic isolation of populations, which preserves the dominant self-mating breeding system of the species. Individual populations of $M$. transsilvanica are characterized by isolated gene pools differing by a small number of loci.
\end{abstract}

KEY WORDS: Melica transsilvanica, Melica ciliata, AFLP, genetic diversity, habitat fragmentation, nonrandom mating.

\section{INTRODUCTION}

Melica L. is the only genus of Poaceae that comprises exclusively diploid species. Stebbins (1950) believes that, in contrast to most other grass genera, the genus Melica consists of the most homogenous or only slightly variable species that are clearly separated by genetic isolation barriers. Both rare species, characterized by limited occurrence ranges and small populations, as well as widely distributed species belong to this genus (Hempel 1970, 1971; Hultén and Fries 1986; Talavera 1986; Sallés and Marchi 2005). In taxonomic treatments of the genus Melica, sections or subgenera have been recognised mostly on the basis of morphological characters (Papp 1933; Hempel 1970, 1971; Tsvelev 1976; Tutin 1980; Clayton and Renvoize 1986).

Melica ciliata L. was described by Linnaeus (1753) as a species that occurs in rocky and infertile hills of Europe.
Its lectotype was designated by Cope (Cafferty et al. 2000) but the exact place of its collection in Europe by Linnaeus in unknown. Melica transsilvanica Schur was described and distinguished from $M$. ciliata by Schur (1866) from the vicinity of the town of Sibiu in upland Transylvania in Romania. Its lectotype was designated by Hempel (2004).

Melica transsilvanica is characterized by a great morphological variability, especially the pigmentation and the degree of convolution of the leaf, distribution and length of hairs on the vegetative parts of the plant, height and number of nodes of the culm, and the width, density and degree of branching of the panicle. $M$. transsilvanica has sometimes been treated as a subspecies or as a variety of $M$. ciliata in European floras (Zapałowicz 1906; Beldie 1979) whereas these taxa have mostly been recognized as two species with minor subspecific taxonomic units elsewhere (Szafer et al. 1953; Hempel 1970; Tsvelev 1976; Tutin 1980; Conert 1998). 
Preliminary phenetic and cladistic analyses within the Meliceae tribe, based on morphological and anatomical surveys, show two recognizable groups within the genus Meli$c a$. The first group comprises North American Melica species combined with some Euroasian species which share characters such as rachilla disarticulation above the glumes, the lemma shorter than the glumes and large spikelets with several florets. The second group comprises widely distributed Melica species, including $M$. transsilvanica and $M$. ciliata, which share characters such as rachilla disarticulation below the glumes and the spikelets being reduced in both the size and the number of florets (1-3 florets) (Mejia-Saulés and Bisby 2000).

Relatively few molecular studies have been performed on Melica species. Analyses of allozyme variation within Melica nutans L. show that this species exhibits a level of genetic differentiation lower than expected despite its wide boreo-nemoreal range (Tyler 2002a). M. ciliata and $M$. transsilvanica were found to be two most genetically similar species in the group of the studied Melica species. $M$. transsilvanica showed no unique alleles, and the greatest number of shared alleles in the study material was recorded between $M$. ciliata and M. transsilvanica. This finding is consistent with the general belief that these two species are closely related (Tyler 2002a). The analysis of genetic variation of putative $M$. ciliata from Poland indicated the lack of any shared AFLP markers with $M$. ciliata individuals from the European centre of range. Hence, the occurrence of 'pure' specimens of $M$. ciliata is problematic in Poland (Szczepaniak and Cieślak 2006).

Recent studies prove that Melica ciliata s. lato, including $M$. transsilvanica and other related taxa, is allozymatically highly variable, with a peculiar mode of inheritance (Tyler 2004). Tyler recognizes three main geographic groups: the first is distributed mainly in Siberia and Eastern Europe, the second in Iberia, and the third in France and Germany. Two or three additional genetic groups containing populations from the Baltic basin, central Europe and south-eastern Europe may be recognized but it is suggestive that these are partly or exclusively formed by introgression between the three previous groups. However, these groups only partly correspond well to the pattern of morphological variation and distribution of particular taxa described by Hempel (1970) and Tutin (1980).

Melica transsilvanica represents the Irano-Turanian geographical element, and its distribution ranges from central Asia, the Middle East, central Europe to Western Europe (Hultén and Fries 1986). The species is rare in the Polish flora, where it reaches the northern limit of its continuous range (Hultén and Fries 1986). It occurs in southern Poland, mostly in the Sudeten Mts, in the Pieniny Mts and in the Kraków-Częstochowa Upland (Szczęśniak 2001; Zając and Zając 2001). M. transsilvanica is characterized by a broader range of ecological tolerance than $M$. ciliata. It grows in grasslands belonging to the Festuco-Brometea class, both on dry, exposed outcrops in pioneer rupicolous grasslands belonging to the Seslerio-Festucion duriusculae alliance, where it is a character species (in the Festucetum pallentis association) and in xerothermic grasslands with a high participation of dicotyledonous perennials of the Cirsio-Brachypodion pinnati alliance (in the Origano-Brachypodietum pinnati association). $M$. transsilvanica is also found in xerothermophilous formations of the Berberidion alliance, on basic or neutral soils, formed on shale or limestone, sometimes rich in nitrogen compounds (Oberdorfer 2001). In Poland, M. transsilvanica occurs only at 11 localities in the Sudetes Mts (Szczęśniak 2001) while it is a locally frequent species in the Pieniny Mts and the Kraków-Częstochowa Upland (own observations). The number of tufts in individual populations varies greatly: from a few in mountainous localities on rocky ledges to a few thousand at lower altitudes.

Melica transsilvanica is a diploid with $2 n=18(x=9)$. This chromosome number is very consistent and has been established from different parts of the species' distribution (Fedorov 1969; Moore 1982). Diploids have also been confirmed in the Pieniny Mts in Poland (Frey 1971). There are no empirical investigations concerning the biology of this species, and in particular its mating system. Allozyme studies on $M$. transsilvanica and related species have revealed significant deviations from Hardy-Weinberg equilibrium indicating selfing with high probability (Tyler 2004).

Phylogenetic and taxonomic relationships between Melica ciliata and $M$. transsilvanica have not been satisfactorily explained and established (Hempel 1970; Tutin 1980; Tyler 2004). It is still disputed whether $M$. transsilvanica should be treated as a separate species or as a subspecies within $M$. ciliata. Distribution ranges of the species overlap in Europe (Meusel et al. 1965; Hultén and Fries 1986), and both occur in similar habitats: on screes, exposed outcrops, and in steppe communities. Great variability of diagnostic morphological characters, such as the ratio of the length of glumes and the hairiness of the lower sheaths, and, at the same time, the formation of the hybrid taxon M. ×thuringiaca Rauschert (Rauschert 1963), make identification of the species within the $M$. ciliata - M. transsilvanica complex difficult. Detailed taxonomic studies, based on common analyses of genetic variability, morphological and phylogenetic relationships, are required to determine the ranks of taxa within the complex.

The main goal of this study was to investigate the level of inter- and intrapopulation genetic variation of Melica transsilvanica. The following factors were analyzed: (1) degree of isolation of neighbouring populations (microgeographic isolation) that additionally occur at the edge of the distribution range of the species, and (2) the nonrandom mating system of this species, predominantly selfing. Furthermore, a preliminary assessment of interspecific distinction between $M$. ciliata and $M$. transsilvanica is given. The study is the first part of a project investigating the level and structure of genetic and morphological differentiation of $M$. transsilvanica and $M$. ciliata in Poland with regard to representatives of these species as well as related species growing in the centre of their European distribution.

In the present study, genetic variation and population structure were assessed using the Amplified Fragment Length Polymorphism (AFLP) method (Vos et al. 1995). AFLP analysis has been used as a reliable method in drawing taxonomic relationships at specific and population levels in many plant groups, particularly with fragmented habitats (Juan et al. 2004). AFLP markers were found useful in estimating microgeographic isolation by distance between populations (Hardy 2003). It is a very effective method of investigating closely related taxa characterized by a low level of genetic diversity (O'Hanlon et al. 2000), and has also been used to elucidate the mode of reproduction (Larson et al. 2001). 


\section{MATERIAL AND METHODS}

\section{Material \\ Sample collection}

Leaves were sampled from 2 to 12 randomly chosen individuals (a total of 68) from tufts situated approximately 5-6 $\mathrm{m}$ from one another in five Polish (the Pieniny Mts and the Kraków-Częstochowa Upland) and two other central European (Austria and Slovakia) natural populations of Melica transsilvanica (Table 1). Specimens from two populations of Melica ciliata collected in Croatia and Slovenia (a total of 24) were also analyzed to establish initially taxonomic relationships between $M$. transsilvanica and $M$. ciliata. Harvested leaves were immediately dried in polyethylene bags with silica gel upon collection in the field and stored prior to DNA extraction. Voucher specimens are deposited in the herbarium of the W. Szafer Institute of Botany, Polish Academy of Sciences, in Cracow (KRAM).

\section{Methods}

\section{DNA extraction and AFLP fingerprinting}

Genomic DNA was extracted with the DNeasy Plant Mini Kit (Qiagen) according to the manufacturer's protocol using about $20 \mathrm{mg}$ of dry leaf tissue. DNA integrity was estimated on $1.5 \%$ agarose gels, and DNA concentration was determined spectrophotometrically using a Gene Quant RNA/DNA calculator (Pharmacia, Uppsala, Sweden).

AFLP analysis was performed according to the procedure described by Vos et al. (1995) with some modifications. Genomic DNA was digested with two restriction enzymes: EcoRI and MseI (New England Biolabs, Inc.). The resulting fragments were ligated to end-specific EcoRI and MseI with double standard adaptors.

The PCR amplification was carried out in two steps: preselective and selective amplification. The PCR preselective amplification was performed using primers with a single selective nucleotide: $E c o \mathrm{RI}+\mathrm{A}$ and $\mathrm{Mse}+\mathrm{C}$, and products were verified on $1.5 \%$ agarose gels. Twelve selective am- plification PCR primer pair combinations were tested. Then, the selection of combinations was based on the number of polymorphic and reproducible fragments and the value of genotyping error $(<$ or $=2 \%)$. Several samples were used in double copies as controls for each analysis to check genotypic error, and independent AFLP reactions were performed in every gel run (Bonin et al. 2004; Meudt and Clarke 2007). Primer screening on three individuals of every species was conducted in the preliminary experiment. The final selective amplification was performed using EcoRI and MseI primers with three selective nucleotides: EAAT-MCAC, EATC-MCAT and EAGA-MCGT which revealed the greatest number of polymorphic, well-separated and reproducible bands. EcoRI primers were fluorescence-labelled with FAM-6 in this reaction. The AFLP products were separated electrophoretically using an ABI Prism 3100-Avant automated sequencer with the internal size standard GeneScan 500 Rox (Applied Biosystems).

Raw data were collected and aligned with the size standard using the GeneScan Analysis software (ver. 3.7, Applied Biosystem) and further examined using Genographer software (ver. 1.6.0, Benham 2001). AFLP fragments (bands) were scored in the range between 50-500 bp and assembled as a binary present (1) and absent (0) matrix for further data analysis.

\section{Data analysis}

AFLP data were analyzed using the phenotypic approach that does not assume Hardy-Weinberg equilibrium, not expected for the probably selfing or mixed-mating Melica transsilvanica (Tyler 2004).

\section{Genetic differentiation within populations}

Genetic diversity within each population was evaluated as the number of polymorphic loci, percentage of polymorphic loci $(P)$, number of AFLP phenotypes, average gene diversity over loci (= gene diversity in a population), genetic similarities (GS) between individuals within a popula-

TABLE 1. Locations of Melica transsilvanica and $M$. ciliata accessions analyzed for AFLP.

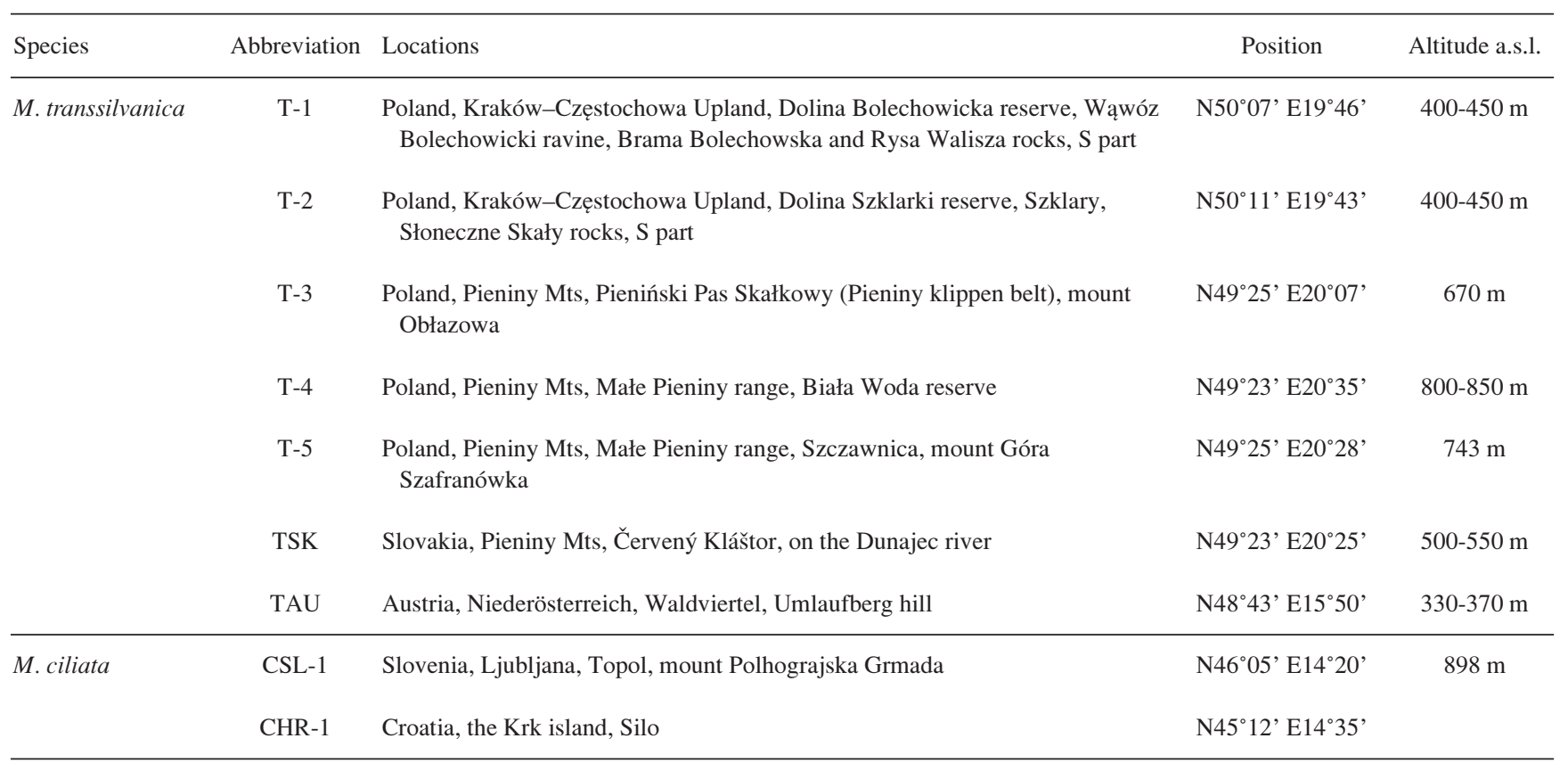


TABLE 2. Population genetic variation of Melica transsilvanica and $M$. ciliata. Population labels correspond to abbreviations given in Table 1.

\begin{tabular}{|c|c|c|c|c|c|c|c|}
\hline Population & $\begin{array}{l}\text { Sample } \\
\text { size } \\
(N)\end{array}$ & $\begin{array}{c}\text { No. of } \\
\text { polymorphic } \\
\text { loci }\end{array}$ & $\begin{array}{c}\% \text { of } \\
\text { polymorphic } \\
\text { loci }(P)\end{array}$ & $\begin{array}{c}\text { No. of AFLP } \\
\text { phenotypes }\end{array}$ & $\begin{array}{c}\text { Average gene } \\
\text { diversity over loci } \\
( \pm \mathrm{SD})\end{array}$ & $\begin{array}{c}\text { Shannon } \\
\text { diversity index } \\
(H \pm \mathrm{SD})\end{array}$ & $\begin{array}{l}\text { Range of } \\
\text { Nei \& Li's (1979) } \\
\text { genetic similarities (GS) }\end{array}$ \\
\hline \multicolumn{8}{|c|}{ M. transsilvanica } \\
\hline $\mathrm{T}-1$ & 12 & 32 & 10.88 & 11 & $\begin{array}{c}0.0359 \\
( \pm 0.0198)\end{array}$ & $\begin{array}{c}0.0579 \\
( \pm 0.1757)\end{array}$ & $0.9290-0.9980$ \\
\hline $\mathrm{T}-2$ & 10 & 3 & 1.02 & 3 & $\begin{array}{c}0.0029 \\
( \pm 0.0025)\end{array}$ & $\begin{array}{c}0.0066 \\
( \pm 0.0651)\end{array}$ & $0.9910-1$ \\
\hline $\mathrm{T}-3$ & 12 & 2 & 0.68 & 3 & $\begin{array}{c}0.0011 \\
( \pm 0.0014)\end{array}$ & $\begin{array}{c}0.0026 \\
( \pm 0.0365)\end{array}$ & $0.9950-1$ \\
\hline $\mathrm{T}-4$ & 12 & 4 & 1.36 & 5 & $\begin{array}{c}0.0032 \\
( \pm 0.0026)\end{array}$ & $\begin{array}{c}0.0061 \\
( \pm 0.0550)\end{array}$ & $0.9950-1$ \\
\hline $\mathrm{T}-5$ & 10 & 10 & 3.40 & 7 & $\begin{array}{c}0.0106 \\
( \pm 0.0068)\end{array}$ & $\begin{array}{c}0.0162 \\
( \pm 0.0932)\end{array}$ & $0.9760-1$ \\
\hline TAU & 10 & 13 & 4.42 & 7 & $\begin{array}{c}0.0106 \\
( \pm 0.0068)\end{array}$ & $\begin{array}{c}0.0179 \\
( \pm 0.0938)\end{array}$ & $0.9670-1$ \\
\hline $\begin{array}{l}\text { Mean } \\
\text { for population }\end{array}$ & & 10.86 & 3.69 & 5.43 & $\begin{array}{c}\mathbf{0 . 0 1 5 0} \\
( \pm 0.0164)\end{array}$ & $\begin{array}{c}\mathbf{0 . 0 1 8 9}-\boldsymbol{H}_{\mathbf{S}} \\
( \pm 0.0189)\end{array}$ & 0.9418 \\
\hline Total for species & 68 & 76 & 25.85 & & $\begin{array}{c}\mathbf{0 . 0 7 5 1} \\
( \pm 0.0372)\end{array}$ & $\begin{array}{c}\mathbf{0 . 1 2 0 8}-\boldsymbol{H}_{\mathbf{T}} \\
( \pm 0.2235)\end{array}$ & \\
\hline \multicolumn{8}{|c|}{ M. ciliata } \\
\hline CSL-1 & 12 & 2 & 0.68 & 3 & $\begin{array}{c}0.0016 \\
( \pm 0.0017)\end{array}$ & $\begin{array}{c}0.0043 \\
( \pm 0.0527)\end{array}$ & $0.9950-1$ \\
\hline CHR-1 & 12 & 48 & 16.33 & 11 & $\begin{array}{c}0.0681 \\
( \pm 0.0365)\end{array}$ & $\begin{array}{c}0.0905 \\
( \pm 0.2109)\end{array}$ & $0.9040-1$ \\
\hline Total for species & 24 & 50 & 17.01 & & $\begin{array}{c}\mathbf{0 . 0 7 6 1} \\
( \pm 0.0387)\end{array}$ & $\begin{array}{c}\mathbf{0 . 1 1 6 1}-\boldsymbol{H}_{\mathbf{T}} \\
( \pm 0.2394)\end{array}$ & \\
\hline
\end{tabular}

tion (Nei and Li 1979), and Shannon's diversity index $(H)$ (Table 2). Shannon's diversity index was calculated as:

$$
H=-\sum p_{i} \log _{2} p_{i}
$$

where $n$ is the total number of AFLP fragments, and $p_{i}$ is the frequency of the $i$ th AFLP fragment (Lewontin 1972). $H$ was calculated for two levels: average diversity within populations $\left(H_{\mathrm{S}}\right)$ and total diversity within the species $\left(H_{\mathrm{T}}\right)$. Polymorphic loci, average gene diversity and the number of AFLP phenotypes were obtained with Arlequin 2.0 (Schneider et al. 2000), genetic similarities were calculated with MVSP ver. 3.1 (Kovach 1999), and Shannon's indices were estimated with Popgene ver. 1.31 (Yeh et al. 1997).

\section{Genetic differentiation between populations}

Species-specific AFLP fragments of Melica transsilvanica and M. ciliata as well as microgeographic region-specific AFLP fragments of $M$. transsilvanica were searched.

All pairs of AFLP phenotypes were analysed using the neighbour-joining (NJ) clustering method based on the Nei and Li similarity coefficients (GS) (Nei and Li 1979). Principal coordinates analysis (PCoA) was done on the Euclidean distances matrix of AFLP data (Gower 1966). NJ and
PCoA were performed with MVSP ver. 3.1 software (Kovach 1999) and were applied to resolve patterns of intraspecific genetic variation and relationships among the studied species.

Genetic variance components and their significance levels were estimated by Analysis of Molecular Variance (AMOVA; Excoffier et al. 1992) and calculated for variations: 1) among species (M. transsilvanica vs. $M$. ciliata); 2) among microgeographic regions of the occurrence of M. transsilvanica (the Pieniny Mts vs. the Kraków-Częstochowa Upland), and 3) among all populations of M. transsilvanica. Variance components were also used to calculate fixation indices (phi-statistics: $\Phi_{\mathrm{ST}}, \Phi_{\mathrm{CT}}$ and $\Phi_{\mathrm{SC}}$ ) and their significance at each level of the hierarchical genetic structure. AMOVA is based on the nonparametric permutation approach and on pairwise squared Euclidean distances between AFLP phenotypes (Excoffier et al. 1992), and was performed using Arlequin 2.0 (Schneider et al. 2000).

\section{RESULTS}

\section{Genetic distinction between species}

Three useful primer combinations gave a total of 294 clearly identifiable and reproducible bands of which 90 
TABLE 3. Distribution of species-specific and microgeographic region-specific AFLP fragments for three primer pairs for Melica transsilvanica and $M$. ciliata, and for subpopulations of M. transsilvanica from Poland; K. Cz. U. - the Kraków-Częstochowa Upland, P. Mts - the Pieniny Mts

\begin{tabular}{|c|c|c|c|c|c|}
\hline \multirow{2}{*}{$\begin{array}{l}\text { Primer } \\
\text { combination }\end{array}$} & \multirow{2}{*}{$\begin{array}{l}\text { Overall number } \\
\text { of } \\
\text { AFLP fragments }\end{array}$} & \multicolumn{2}{|c|}{$\begin{array}{l}\text { Species-specific } \\
\text { AFLP fragments of }\end{array}$} & \multicolumn{2}{|c|}{$\begin{array}{l}\text { Region-specific } \\
\text { AFLP fragments of }\end{array}$} \\
\hline & & M. transsilvanica & M. ciliata & $\begin{array}{l}\text { M. transsilvanica } \\
\text { from K. Cz. U. }\end{array}$ & $\begin{array}{l}\text { M. transsilvanica } \\
\text { from P. Mts }\end{array}$ \\
\hline EAAT-MCAC & 108 & 17 & 9 & 3 & 2 \\
\hline EATC-MCAT & 132 & 21 & 22 & 2 & 2 \\
\hline Total & 294 & $\begin{array}{c}\mathbf{5 0} \\
(17.00 \%)\end{array}$ & $\begin{array}{c}40 \\
(13.61 \%)\end{array}$ & $\begin{array}{c}5 \\
(1.70 \%)\end{array}$ & $\begin{array}{c}5 \\
(1.70 \%)\end{array}$ \\
\hline Mean & 98.00 & 16.67 & 13.33 & 1.67 & 1.67 \\
\hline SD & 39.95 & 4.51 & 7.51 & 1.53 & 0.58 \\
\hline
\end{tabular}

$(30.61 \%)$ were polymorphic between 92 individuals of $\mathrm{Me}$ lica transsilvanica and $M$. ciliata. $M$. transsilvanica is characterized by $50(17.00 \%)$ and $M$. ciliata by $40(13.61 \%)$ unique, species-specific AFLP fragments (Tables 2 and 3).

Phenetic relationships among Melica ciliata and M. transsilvanica samples based on the Nei and Li similarity matrix showed the NJ grouping of almost all individuals within their own populations and the clustering of the populations within the species (Fig. 1). A few individuals which do not join within their populations were grouped, however, within subclusters corresponding to the microgeographic regions of Poland: the Kraków-Częstochowa Upland and the Pieniny Mts (Fig. 1).

The genetic division between the species along the first axis was also clearly reflected in the PCoA of the genetic data set (Fig. 2). The first and second principal coordinates explained the $70.36 \%$ and $10.06 \%$, respectively, of total genetic variation within the study material.

AMOVA confirmed the significance of genetic differences between Melica transsilvanica and M. ciliata $(82.21 \%$, $p<0.029$; Table 4) and the grouping of their populations in NJ.
Genetic differentiation within and between populations of Melica transsilvanica

Low levels of genetic diversity were found within populations of Melica transsilvanica. However, genetic variation was different in individual populations. Therefore, the greatest number and the highest percentage of polymorphic AFLP loci (32 and $10.88 \%$, respectively) were found in population T-1 of $M$. transsilvanica, and they were the lowest ( 2 and $0.68 \%$ ) in population T-3 (Table 2). On average, 10.86 polymorphic AFLP loci and $3.69 \%$ of polymorphic loci were detected per population.

Melica transsilvanica populations also differ by the number of the determined AFLP phenotypes in relation to the number of plants studied in each population. Almost all specimens presented a unique AFLP phenotypes in population T-1 (11 AFLP phenotypes within 12 individuals), whereas only 3 AFLP phenotypes were detected in populations T-2 and T-3 within 10 and 12 individuals, respectively (Table 2). On average, 5.43 AFLP phenotypes were found within populations of M. transsilvanica.



Fig. 1. Neighbour-joining (NJ) tree constructed for 7 populations (68 specimens) of Melica transsilvanica and 2 populations (24 specimens) of M. ciliata, using the genetic similarities of Nei and Li (1979), based on 294 AFLP fragments. Individuals from geographic regions of Poland are referenced by different symbols: $\mathbf{\Delta}$ - the Kraków-Częstochowa Upland, - the Pieniny Mts; PL - Poland. Population labels correspond to abbreviations given in Table 1. 


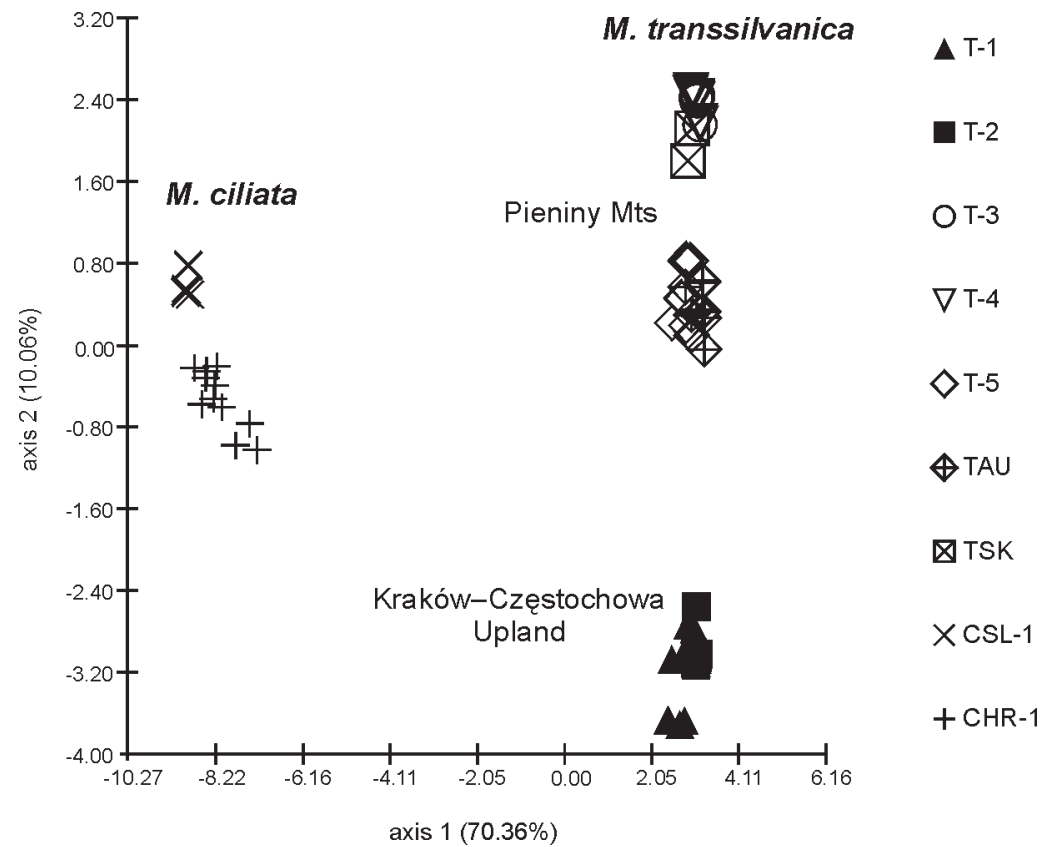

Fig. 2. Principal coordinates analysis (PCoA) of populations of Melica transsilvanica and $M$. ciliata collected in the centre of the European range of species and in geographic regions of Poland (the Kraków-Częstochowa Upland and the Pieniny Mts), based on AFLP data. For abbreviations of particular populations see Table 1 .

TABLE 4. Results of the analysis of molecular variance (AMOVA). Plants represented 7 populations of Melica transsilvanica and 2 populations of $M$. ciliata. The analysis is based on AFLP phenotypes consisting of 294 band states. Levels of significance are based on 1023 iteration steps.

\begin{tabular}{|c|c|c|c|c|c|}
\hline Level of variation & d.f. & $\begin{array}{c}\text { Variance } \\
\text { components }\end{array}$ & $\begin{array}{l}\text { Percentage } \\
\text { of variation }\end{array}$ & $\begin{array}{l}\text { Fixation } \\
\text { index }\end{array}$ & $p$ \\
\hline \multicolumn{6}{|l|}{ A) M. transsilvanica versus $M$. ciliata } \\
\hline Among species & 1 & 62.997 & 82.21 & $\Phi_{\mathrm{CT}}=0.822$ & $<0.029$ \\
\hline Among populations within species & 7 & 11.039 & 14.40 & $\Phi_{\mathrm{SC}}=0.809$ & $<0.001$ \\
\hline Within populations & 83 & 2.597 & 3.39 & $\Phi_{\mathrm{ST}}=0.966$ & $>0.05 \mathrm{NS}$ \\
\hline Total & 91 & 76.633 & 100 & & \\
\hline \multicolumn{6}{|c|}{ B) M. transsilvanica: Kraków-Częstochowa Upland versus Pieniny Mts } \\
\hline Among regions & 1 & 10.304 & 60.89 & $\Phi_{\mathrm{CT}}=0.609$ & $<0.001$ \\
\hline Among populations within regions & 4 & 4.910 & 29.01 & $\Phi_{\mathrm{SC}}=0.742$ & $<0.001$ \\
\hline Within populations & 52 & 1.710 & 10.10 & $\Phi_{\mathrm{ST}}=0.899$ & $>0.05 \mathrm{NS}$ \\
\hline Total & 57 & 16.923 & 100 & & \\
\hline \multicolumn{6}{|c|}{ C) M. transsilvanica: all populations together } \\
\hline Among populations & 6 & 10.957 & 86.03 & $\Phi_{\mathrm{ST}}=0.860$ & $<0.001$ \\
\hline Within populations & 61 & 6.179 & 13.97 & & \\
\hline Total & 67 & 17.136 & 100 & & \\
\hline
\end{tabular}

Genetic similarities (GS) between individuals in Melica transsilvanica populations were very high and ranged from 0.9290 (in population T-1) to 1 (in other populations). When GS $=1$, the individuals are genetically identical, which was found in all the studied populations except T-1 (Table 2). Generally, populations of M. transsilvanica were similar at the level of 0.9418 .

Shannon's index of diversity calculates population differentiation similarly to Nei's $G_{\mathrm{ST}}$ and Wright's $F_{\mathrm{ST}}$ (Weising et al. 2005). Shannon's indices calculated over individual loci in the populations were very low and ranged from 0.0026 in population $\mathrm{T}-3$ to 0.0579 in population $\mathrm{T}-1$. On average $H_{\mathrm{S}}=0.0189$ for populations and $H_{\mathrm{T}}=0.1208$ for the species, which indicates limited genetic variation of Melica transsilvanica (Table 2).

Non-grouped AMOVAs showed a significant and high level of differentiation among Melica transsilvanica populations: $86.03 \%(p<0.001)$, with the overall value $\Phi_{\mathrm{ST}}$ equal 0.860 . The remaining part of the genetic variation
(13.97\%) was resided among individuals within populations (Table 4). $\Phi_{\mathrm{ST}}$ values were significant at $p<0.001$ for all pairwise population comparisons, except $\Phi_{\mathrm{ST}}$ pairwise between populations $\mathrm{T}-1$ and $\mathrm{T}-2$ collected in the Kraków-Częstochowa Upland and between populations T-3 and T-4 collected in the Obłazowa Mt and the Biała Woda reserve, both in the Pieniny Mts, suggesting that populations from the same microgeographic region were not genetically distinct (results not shown).

The analysis of the genetic structure of the populations using grouped AMOVA analysis, based on the grouping of populations obtained in the cluster analysis (Fig. 1), showed genetic distinction on a small spatial geographic scale between $M$. transsilvanica populations from the Kraków-Częstochowa Upland and the Pieniny Mts $(60.89 \%$, $p<0.001$; Table 4). Populations from both the Kraków-Częstochowa Upland and the Pieniny Mts have 5 unique, microgeographic region-specific AFLP fragments (Table 3). The second principal coordinate separated popu- 
lations from the Kraków-Czętochowa Upland and the Pieniny Mts on the PCoA plot, and showed low within-population variation of the AFLP data (Fig. 2).

\section{DISCUSSION}

The obtained results show significant genetic differences between Melica transsilvanica and $M$. ciliata that were also demonstrated in previous analyses (Szczepaniak and Cieślak 2006). These preliminary data allow the taxa to be treated as separate species, and such taxonomic treatment corresponds to various floras (Szafer et al. 1953; Hempel 1970; Tsvelev 1976; Tutin 1980; Conert 1998).

\section{Level of AFLP variation: implications for the breeding system of Melica transsilvanica}

The level of intraspecific genetic variation is mostly conditioned by the breeding system (Hamrick and Godt 1996). Outcrossers are usually characterized by greater total genetic variation and smaller interpopulation differentiation than selfers and clonal species (Hamrick and Godt 1990). Each population is different from but similar to the neighbouring population in outcrossing species as a result of the genetic exchange between such populations. Self-pollinators, on the other hand, tend to form homogenous populations that, however, greatly differ from one another, even for very small distances, as the genetic exchange between them is very low or entirely absent (Stace 1989). An intermediate situation may also occur, and simultaneous or interchangeable cross-fertilization and/or self-fertility may be observed within one population in some species (Campbell et al. 1983; Durand et al. 2000).

The studied populations of Melica transsilvanica are generally characterized by a low level of AFLP genetic variation, with average genetic similarity between individuals close to 1 , which indicates nearly total genetic homogeneity of its populations. Low values of average gene diversity over loci and the Shannon index also support limited intraspecific genetic diversity within $M$. transsilvanica. The values of these genetic parameters confirm and expand results reported earlier by Tyler (2004), who studied allozyme variation within the Melica ciliata complex, including $M$. transsilvanica. The AFLP analysis in the present study resulted in average 5.43 multilocus phenotypes per population and $86.03 \%$ of total genetic diversity resided between populations, whereas the survey of Tyler (2004) gave 3.30 as the mean number of allozyme multilocus genotypes within the populations and $53.00 \%$ of genetic diversity between the populations. It should be noted that if values of allozyme variation and AFLP variation are compared, the latter is slightly higher, which is caused by the efficiency of AFLP method. AFLP technique requires small quantities of DNA and permits on relatively precise estimates the relatedness between individuals on the base on a large number of polymorphic loci, that could compensate for them being individually less informative than codominant markers (Hardy 2003). However, a similar partitioning of inter- and intrapopulation genetic variation of $M$. transsilvanica with the use of different markers should be emphasized.

A low level of intraspecific genetic variation can be caused by the nonrandom mating system of species and results in the occurrence of inbreeding in populations. Keller and
Waller (2002) notice that there exists a number of definitions of inbreeding. The term "inbreeding" is used to describe various related phenomena; they all, however, refer to mating which occurs among relatives and to an increase in homozygosity associated with such mating (Weising et al. 2005). The present results indicate a high level of inbreeding in the populations of Melica transsilvanica which can be related to two phenomena. Firstly, it can be associated with nonrandom mating where an individual is considered inbred if its parents were related more closely than two randomly chosen individuals. Secondly, inbreeding can be caused by population subdivision where subpopulations are more or less isolated groups with restricted size in which genetic drift results can be observed (Keller and Waller 2002). In $M$. transsilvanica nonrandom mating can be achieved through two modes: self-fertility and/or apomixes, as suggested in results of previous studies (Tyler 2004). The data obtained in our study indicate that the intrapopulation genetic diversity of $M$. transsilvanica was lower than the mean value for other self-fertilizing plant species. On average, $M$. transsilvanica populations contained $3.69 \%$ polymorphic loci $(P)$ and genetic diversity was $0.0189\left(H_{\mathrm{S}}\right)$, whereas a review by Hamrick and Godt (1990) shows that $20 \%$ of loci were polymorphic and mean genetic diversity was 0.074 within the average population for selfing species.

Large reductions in genetic variability within populations and increased differentiation among populations have also been observed in other self-fertilizing grasses (Price et al. 1984; Larson et al. 2001). Genetic diversity of Melica transsilvanica is lower than that found in other facultative self-pollinating grass species, e.g. Elymus caninus (Díaz et al. 1999) or Elymus alaskanus (Sun et al. 2002), but comparable with the level of genetic variation found in obligate self-pollinators, e.g. Bromus tectorum (Bartlett et al. 2002; Ramakrishnan et al. 2004) or in the self-compatible Calamagrostis porteri subsp. insperata (Esselman et al. 1999).

Most studies do not use direct estimates of selfing rates for each taxon (Takebayashi and Morrell 2001). There are no experimental data available on the breeding system of Melica transsilvanica, instead, however, indirect data such as more or less cleistogamic spikelets, diploid number of chromosomes or the level of genetic variation indicative of the mating system can be used. $M$. transsilvanica is a perennial species, with short rhizomes and panicle inflorescence, with spikelets comprising 1 fertile (hermaphroditic) floret and 2-3 diminished florets at the apex. The features of floral structures of $M$. transsilvanica, e.g. small anthers and relatively closed flowers, may indicate that it is a highly self-pollinated species, similarly to another grass, Elymus alaskanus (Sun et al. 2002). In their review of cleistogamy in grasses, Campbell et al. (1983) emphasize that the majority of cleistogamic species are perennial as well as tufted, and that about $55 \%$ of these perennials are considered to be plants of early successional habitats. Selective pressures of such habitats can lead to the development of cleistogamy. M. transsilvanica typically occurs on shallow soil, in xerothermic grasslands where the moisture-holding capacity is low, and it is resistant to summer droughts (Tyler 2004). In such species, cleistogamy is often facultative, appearing to be a secondary form of seed setting that occurs in disadvantageous conditions during inflorescence development (Campbell et al. 1983). 
The present results show that a high level of self-fertilization rather than apomixes occurs in Melica transsilvani$c a$, or the co-occurrence of both these processes, with dominant selfing and even occasional outcrossing, is probable. On the other hand, facultative apomixes in Melica ciliata s. lato (including M. transsilvanica), also suggested by Tyler (2004) as a possible mode of seed formation, is not congruent with the high number of allozymatic multilocus genotypes, differing in the number and combination of a relatively limited number of alleles, observed by him. Tyler (2004) notices that "if apomixis is only facultative, and/or recombination among loci occurs by some process other than sexual reproduction, patterns similar to those observed in Melica ciliata s. lato might be expected". Selffertilization is not a frequent phenomenon in nature, and only $20-25 \%$ of plant taxa are predominantly selfing (Barrett and Eckert 1990). However, selfing is more common in Poaceae than in any other angiosperm families (Sanders and Hamrick 1980; Campbell et al. 1983; Díaz et al. 1999). At the same time, some contribution of outcrossing has been observed in various self-pollinating grass species, even in predominantly autogamous ones, e.g. Elymus caninus (Díaz et al. 1999), Elymus canadensis (Sanders and Hamrick 1980), which is shown by the florets open during anthesis. Furthermore, three origins of seeds have been confirmed in other species, e.g. Hyparrhenia diplandra, savanna grass, in which apomixis is dominant but some seeds originate from self-fertilization and from outcrossing (Durand et al. 2000).

\section{Geographic patterns of genetic variation of Melica transsilvanica in Poland}

In Poland, Melica transsilvanica occurs mainly in communities of the Festuco-Brometea class and belongs to species occurring on soils rich in calcium carbonate. It grows on relatively shallow rendzina soils derived from calcareous or limestone rocks and considerably less frequently on soils derived from igneous rocks. Thus, suitable habitats for this species are strongly fragmented, and microgeographic isolation is noticeable between populations from the Pieniny Mts, the southern part of the Kraków-Częstochowa Upland and the Sudeten Mts. Due to habitat requirements, $M$. transsilvanica also owns scattered locations in the northern and western parts of its distribution in Europe, where it mainly occurs in rocky habitats, on outcrops of limestone or ultrabasic bedrock or screes. M. transsilvanica is also a component of steppe communities in the eastern part of its distributions range.

A distribution-dependent level of genetic variability has been analyzed for many species. It was observed that populations occured in small, isolated habitats are characterized by levels of variation lower than those populations that occur in relatively continuous habitats (Tyler 2002b). Therefore population fragmentation, even in common species, caused a reduction in gene flow and a decrease in interpopulation genetic differentiation. The isolation by distance in connection with fragmented habitats is in particular significantly responsible for the distribution of genetic variation within narrowly endemic species (Jiménez et al. 2005).

The magnitude and the pattern of gene flow is an important factor that influences the resulting size and genetic structure of populations. Gene flow between populations can be realized by pollen and/or seed migrants. Seeds per- form an important role in the colonization of new areas. Pollen is an effective mode of gene spreading in areas that have already become colonized (Avise 1994; McCauley 1997). The finding that few AFLP phenotypes were shared only between neighbouring populations of Melica transsilvanica in a small geographic scale (populations T-1 and T-2 shared only 3 AFLP phenotypes, and populations T-3 and T-4 had 11 common AFLP phenotypes), strongly suggests that gene flow between all the populations is very limited or totally lacking. The level of genetic distinction detected among populations of $M$. transsilvanica is unexpectedly high, especially considering that seeds of $M$. transsilvanica are enclosed in specialized dispersal structures such as dense, long hairy lemmas, which facilitates spreading by wind. Results of experimental and structural investigations on various anemochorous species show that $M$. ciliata is the best flier due to their hairy lemmas (very similar to $M$. transsilvanica in this respect) that are efficient for wind dispersal (Hensen and Müller 1997). On the other hand, the wind dispersal potential of species not only depends on the morphology of its diaspores but is the most sensitive to weather conditions and falling velocity. The better species-specific anemochorous traits of diaspores, such as lower height and low falling velocity, the greater the increase in the wind dispersal potential (Tackenberg et al. 2003). Fragmentation of $M$. transsilvanica habitats in Europe may reduce pollen and seed migrations and thus increase levels of selfing in populations of self-compatible species, and finally lead to an extremely low level of genetic diversity in some populations of $M$. transsilvanica.

AMOVA confirmed the significance of genetic differences between the populations of Melica transsilvanica collected in the Kraków-Częstochowa Upland and in the Pieniny Mts (including specimens collected in the Slovak Pieniny Mts). Independent mutations that are randomly fixed for a similar pressure of habitat factors in both geographic regions may occur in such subpopulations of $M$. transsilvanica. Subpopulations of $M$. transsilvanica are genetically similar but not identical and differ by changes in a small number of loci. Additionally, the influence of genetic drift increases in small-size, isolated populations, and in effect random phenomena can occur. Change fixation may also be caused by the founder effect, particularly in unstable and changing habitat conditions where a limited initial genepool, including subpopulation isolation, causes certain interspecific genetic differences (Sherman-Broyles et al. 1992). Tyler (2004) notices that high proportions of between-population variation of Melica ciliata s. lato may also be due to cryptic speciation or to the presence of several partially isolated gene pools.

The analysis of genetic variation of Melica transsilvani$c a$ at the metapopulation level, assuming a model without extinctions, showed that a metapopulation can maintain large amounts of genetic variation that is sometimes greater than in outcrossing species, which supports models of metapopulation dynamics and empirical studies (Poschlod et al. 1998; Pannell and Charlesworth 2000; Ingvarsson 2002). This is due to the fact that as selfing increases, pollen migration is reduced and levels of genetic differentiation among local populations are increased. Ingvarsson (2002) finds that metapopulation processes should be viewed as a viable alternative explanation for a large reduction in genetic variation seen in highly selfing species. 


\section{CONCLUSIONS}

Preliminary results of the present study indicate genetic distinction between Melica transsilvanica and M. ciliata. The low level of genetic variability in the populations of M. transsilvanica collected in Poland can be caused by:

- reproduction mode, i.e. likely occurrence of dominant facultative self-fertilization (more probable than prevailing facultative apomixes) with sporadic outcrossing,

- geographic isolation of local populations, connected with fragmented habitats of the species, which limits gene flow among populations,

- geographic location of the Polish populations of $M$. transsilvanica at the edge of the continuous distribution range of the species, i.e. border effects.

The present results suggest that selection and mating mode influenced the partitioning of AFLP variation and quantitative morphological differences among natural populations of Melica transsilvanica. A hierarchical geographic analysis of genetic differences using allozymatic markers was recently performed but it did not provide a clear pattern of taxonomic relationships within the M. ciliata M. transsilvanica complex (Tyler 2004). The examination of population genetic variation of Melica transsilvanica in the microgeographic scale of Poland, conducted in the present paper, serves as the starting point for such an analysis in a macrogeographic scale comprising the European range of the species. It is necessary to combine both present and previous results with a detailed analysis of morphological and cytological variation, especially to ascertain the existence of a hybrid between $M$. ciliata and $M$. transsilvanica. This will permit us to define the range of species variation and will also confirm its mode of reproduction.

\section{ACKNOWLEDGEMENTS}

The authors thank Dr. Beata Paszko, Dr. Joanna Zalewska-Gałosz and Dr Gerald M. Schneeweiss for the sampled specimens. This work was supported by the Polish Ministry of Science and Higher Education, grant no. 3 P04G 04025 .

\section{LITERATURE CITED}

AVISE J.C. 1994. Molecular markers, natural history and evolution. Chapman and Hall, New York.

BARRETT S.C.H., ECKERT C.G. 1990. Variation and evolution of mating systems in seed plants. In: Biological Approaches and Evolutionary Trends in Plants. Kawano S. (ed.). Academic Press, Tokyo, pp. 229-254.

BARTLETT E., NOVAK S.J., MACK R.N. 2002. Genetic variation in Bromus tectorum (Poaceae): differentiation in the eastern United States. Amer. J. Bot. 89 (4): 602-612.

BELDIE A.L. 1979. Flora României. Determinator ilustrat al plantelor vasculare. Vol. 2. Editura Academiei Republicii Socialiste România, Bucureşti, 406 pp.

BENHAM J.J. 2001. Genographer, version 1.6.0. Montana State University, http://hordeum.oscs.montana.edu/genographer

BONIN A., BELLEMAIN E., BRONKEN EIDESEN P., POMPANON F., BROCHMANN C., TABERLET P. 2004. How to track and assess genotyping errors in population genetics studies. Mol. Ecol. 13: 3261-3273.
CAFFERTY S., JARVIS C.E., TURLAND N.J. (eds). 2000. Typification of Linnaean plant names in the Poaceae (Gramineae). Taxon 49 (2): 239-260.

CAMPBELL C.S., QUINN J.A., CHEPLICK G.P., BELL T.J. 1983. Cleistogamy in Grasses. Ann. Rev. Ecol. Syst. 14: 411$-441$.

CLAYTON W.D., RENVOIZE S.A. 1986. Genera Graminum. Grasses of the world. Her Majesty's Stationery Office, London. 389 pp.

CONERT H.J. (ed.). 1998. Gustav Hegi Illustrierte Flora von Mitteleuropa. Spermatophyta: Angiospermae: Monocotyledones 1 (2), Poaceae. Band I, teil 3. Parey Buchverlag, Berlin, $928 \mathrm{pp}$.

DÍAZ O., SALOMON B., VON BOTHMER R. 1999. Genetic diversity and structure in populations of Elymus caninus (L.) L. (Poaceae). Hereditas 131: 63-74.

DURAND J., GARNIER L., DAJOZ I., MOUSSET S., VEUILLE M. 2000. Gene flow in a facultative apomictic poacea, the savanna grass Hyparrhenia diplandra. Genetics 156: 823-831.

ESSELMAN E.J., JIANQIANG L., CRAWFORD D.J., WINDUS J.L., WOLFE A.D. 1999. Clonal diversity in the rare $\mathrm{Ca}$ lamagrostis porteri subsp. insperata (Poaceae): comparative results for allozymes and random amplified polymorphic DNA (RAPD) and intersimple sequence repeat (ISSR) markers. Mol. Ecol. 8 (3): 443-451.

EXCOFFIER L., SMOUSE P.E., QUATTRO J.M. 1992. Analysis of molecular variance inferred from metric distances among DNA haplotypes: application to human mitochondrial DNA restriction data. Genetics 131: 479-491.

FEDOROV A.A. 1969. Chromosome numbers of flowering plants. Russian Academy of Sciences, Leningrad, 926 pp.

FREY L. 1971. Chromosome numbers of several species of flowering plants in Poland. Fragm. Flor. Geobot. 17 (2): 251-256 .

GOWER J.C. 1966. Some distance properties of latent root and vector methods used in multivariate analysis. Biometrika 53: 325-328.

HAMRICK J.L., GODT M.J.W. 1990. Allozyme diversity in plant species. In: Plant population genetics, breeding and genetic resources. Brown A.H.D., Clegg M.T., Kahler A.L., Weir B.S. (eds). Sinauer Associates, Sunderland, Massachusetts, USA, pp. 43-63.

HAMRICK J.L., GODT M.J.W. 1996. Effects of life history traits on genetic diversity in plant species. Philos. Trans. R. Soc. Lond. B 351: 1291-1298.

HARDY O.J. 2003. Estimation of pairwise relatedness between individuals and characterization of isolation-by-distance processes using dominant genetic markers. Mol. Ecol. 12 (6): 1577-1588.

HEMPEL W. 1970. Taxonomische und chorologische Untersuchungen an Arten von Melica L. Subgen. Melica. Feddes Repert. 81 (1-15): 131-145.

HEMPEL W. 1971. Die systematische Stellung van Melica uniflora Retz. und Melica rectiflora Boiss. er Heldr. Feddes Repert. 81 (10): 657-686.

HEMPEL W. 2004. Proposal to conserve the name Melica transsilvanica against M. caricina (Poaceae). Taxon 53 (3): 839.

HENSEN I., MÜLLER C. 1997. Experimental and structural investigations of anemochorous dispersal. Plant Ecol. 133 (2): 169-180.

HULTÉN E., FRIES M. 1986. Atlas of North European vascular plants. North of the Tropic of Cancer. Koelz Scientific Books, Königstein, Vol. 1. 498 pp., Vol. 3. 1172 pp.

INGVARSSON P. 2002. A metapopulation perspective on genetic diversity and differentiation in partially self-fertilizing plants. Evolution 56 (12): 2368-2373.

JIMÉNEZ J.F., GÜEMES J., SÁNCHEZ-GÓMEZ P., ROSSELLÓ J.A. 2005. Isolated populations or isolated taxa? A case study in narrowly-distributed snapdragons (Antirrhinum sect. 
Sempervirentia) using RAPD markers. Plant Syst. Evol. 252 (3-4): 139-152.

JUAN A., CRESPO M.B., COWAN R.S., LEXER C., FAY M.F. 2004. Patterns of variability and gene flow in Medicago citri$n a$, an endangered endemic of islands in the western Mediterranean, as revealed by amplified fragment length polymorphism (AFLP). Mol. Ecol. 13 (9): 2679-2690.

KELLER L.F., WALLER D.M. 2002. Inbreeding effects in wild populations. Trends Ecol. Evol. 17 (5): 230-241.

KOVACH W.L. 1999. MVSP - A multi-variate statistical package for windows, ver. 3.1. Kovach computing Services, Penthraeth.

LARSON S.R., CARTIER E., McCRACKEN C.L., DYER D. 2001. Mode of reproduction and amplified fragment length polymorphism variation in purple needlegrass (Nassella pulchra): utilization of natural germplasm sources. Mol. Ecol. 10: 1165-1177.

LEWONTIN R.C. 1972. The apportionment of human diversity. Evol. Biol. 6: 381-398.

LINNAEUS C. 1753. Species plantarum, exihibentes plantas rite cognitas, ad genera relatas, cum differentiis specificis, nomnibus trivialibus, synonymis selectis, locis natalibus secundum systema sexuale digestas. 1. Impensis Laurentii Salvii, Holmiae [Stockholm]. Facsimile ed.: 1957, ed. Ray Society, London, with an introduction by W. Stearn: [iii] - xiv + 1-176 [1-2]: facsimile: [I-xii] + 1-560; and new index to genera and classes [1-6].

McCAULEY D.E. 1997. The relative contributions of seed and pollen movement to local genetic structure of Silene alba. J. Hered. 88: 257-263.

MEJIA-SAULÉS T., BISBY F.A. 2000. Preliminary views on the tribe Meliceae (Gramineae: Pooideae). In: Grasses: systematic and evolution. Jacobs S.W.L. and Everett J. (eds). CSIRO, Melbourne, pp. 83-88.

MEUDT H.M., CLARKE A.C. 2007. Almost forgotten or latest practice? AFLP applications, analyses and advances. Trends Plant Sci. 12 (3): 106-117.

MEUSEL H., JÄGER E., WEINERT E. 1965. Vergleichende Chorologie der Zentraleuropäischen Flora. G. Fischer, Jena, 583 pp. (Text) +258 pp. (Karten).

MOORE D.M. 1982. Flora Europaea. Check-list and chromosome index. Cambridge University Press, Cambridge, 423 pp.

NEI M., LI W.H. 1979. Mathematical model for studying genetic variation in terms of restriction endonucleases. Proc. Nat. Acad. Sci. 76: 5269-5273.

OBERDORFER E. (ed.). 2001. Pflanzensoziologische Excursionsflora für Deutschland und angrenzende Gebiete. 8 Auflage. Verlag Eugen Ulmer, Stuttgart, 1051 pp.

O'HANLON P.C., PEAKALL R., BRIESE D.T. 2000. A review of new PCR-based genetic markers and their utility to weed ecology. Weed Research 40: 239-254.

PANNELL J.R., CHARLESWORTH B. 2000. Effects of metapopulation processes on measures of genetic diversity. Phil. Trans. R. Soc. Lond. B 355 (12): 1851-1864.

PAPP C. 1933. Monographie der europäischen Arten der Gattung Melica L. Bot. Jahrb. 64: 274-348.

POSCHLOD P., KIEFER S., TRÄNKLE U., FISCHER S., BONN S. 1998. Plant species richness in calcareous grasslands as affected by dispersability in space and time. Appl. Veget. Science 1: 75-90.

PRICE S.C., SHUMAKER K.M., KAHLER A.L., ALLARD R.W., HILL J.E. 1984. Estimates of population differentiation obtained from enzyme polymorphisms and quantitative characters. J. Hered. 75: 141-142.

RAMAKRISHNAN A.P., MEYER S.E., WATERS J., STEVENS M.R., COLEMAN C.E., FAIRBANKS D.J. 2004. Correlation between molecular markers and adaptively significant genetic variation in Bromus tectorum (Poaceae), an inbreeding annual grass. Am. J. Bot. 91 (6): 797-803.
RAUSCHERT S. 1963. Die Arten van Melica sect. Beckeria (Bernh.) Asch. in Mitteldeutschland. Ber. Deutsch. Bot. Ges. 74: 235-243.

SALLÉS J.M., MARCHI M.M. 2005. Dos Especies Nuevas del Género Melica L. (Poaceae: Meliceae) del Uruguay. Novon 15 (2): 338-342.

SANDERS T.B., HAMRICK J.L. 1980. Variation in the breeding system of Elymus canadensis. Evolution 34: 117-122.

SCHNEIDER S., ROESSLI D., EXCOFFIER L. 2000. Arlequin ver. 2.000: A software for population genetics data analysis. Genetics and Biometry Laboratory, University of Geneva, Switzerland (http://lgb.unige.ch/arlequin/).

SCHUR J.F. 1866. Enumeratio plantarum Transsilvaniae exhibens. G. Braumüller, Wien, 984 pp.

SHERMAN-BROYLES S.L., GIBSON J.P., HAMRICK J.L., BUCHER M.A., GIBSON M.J. 1992. Comparisons of allozyme diversity among rare and widespread Rhus species. Syst. Bot. 17: 551-559.

STACE C.A. 1989. Plant Taxonomy and Biosystematics. 2nd Ed. Chapman and Hall Inc., New York, 264 pp.

STEBBINS G.L. 1950. Variation and Evolution in Plants. Columbia University Press, New York, 643 pp.

SUN G.-L., SALOMON B., VON BOTHMER R. 2002. Microsatellite polymorphism and genetic differentiation in three Norwegian populations of Elymus alaskanus (Poaceae). Plant Syst. Evol. 234: 101-110.

SZAFER W., KULCZYŃSKI S., PAWŁOWSKI B. 1953. Rośliny polskie. Opisy i klucze do oznaczania wszystkich gatunków roślin naczyniowych rosnących w Polsce bądź dziko, bądź też zdziczałych lub częściej hodowanych [Polish plants. Descriptions and keys to the determination of the wild, naturalized and frequently cultivated vascular plants in Poland]. Państwowe Wydawnictwo Naukowe, Warszawa. xxviii + 1020 pp. (in Polish).

SZCZEPANIAK M., CIEŚLAK E. 2006. Genetic variation and structure in natural populations of Melica ciliata and M. transsilvanica (Poaceae) as indicated by AFLP markers. Biodiv. Res. Conserv. 3-4: 39-43.

SZCZEŚSIAK E. 2001. Preliminary report on Melica sect. Beckeria (Poaceae) in the Lower Silesia. In: Studies on grasses in Poland. Frey L. (ed.). W. Szafer Institute of Botany, Polish Academy of Sciences, Kraków, pp. 153-160.

TACKENBERG O., POSCHLOD P., BONN S. 2003. Assessment of wind dispersal potential in plant species. Ecol. Monogr. 73 (2): 191-205.

TAKEBAYASHI N., MORRELL P.L. 2001. Is self-fertilization an evolutionary dead end? Revisiting an old hypothesis with genetic theories and a macroevolutionary approach. Amer. J. Bot. 88 (7): 1143-1150.

TALAVERA S. 1986. Una Nueva Especie del Género Melica L. Lagascalia 14 (1): 118-119.

TSVELEV N.N. 1976. Zlaki SSSR [Grasses of the USSR]. Izdatel'stvo Nauka, Leningrad, 788 pp. (in Russian)

TUTIN T.G. 1980. Melica L. In: Flora Europaea. 5. Alismataceae to Orchidaceae (Monocotyledones). Tutin T.G., Heywood V.H., Burges N.A., Moore D.M., Valentine D.H., Walters S.M., Webb D.A. (eds). Cambridge University Press, Cambridge, pp. 178-179.

TYLER T. 2002a. Large-scale geographic patterns of genetic variation in Melica nutans, a widespread Eurasian woodland grass. Plant Syst. Evol. 236 (1-2): 73-87.

TYLER T. 2002b. Geographic structure of genetic variation in the widespread woodland grass Milium effusum L. A comparison between two regions with contrasting history and geomorphology. Genome 45 (6): 1248-1256.

TYLER T. 2004. Studies in the Melica ciliata - complex: 1. Distribution of allozyme variation within and among individuals, populations and geographic regions. Plant Syst. Evol. 248 (14): 1-30.

VOS P.R., HOGERS M., BLEEKER M., REIJANS M., VAN DE LEE T., HORNES M., FRIJTERS A., POT J., PELEMAN J., 
KUIPER M., ZABEAU M. 1995. AFLP: a new technique for DNA fingerprinting. Nucleid Acids Res. 23: 4407-4414.

WEISING K., NYBOM H., WOLFF K., KAHL G. 2005. DNA fingerprinting in plants: principles, methods, and applications. CRC Press Taylor and Francis Group, Boca Raton, 2nd ed., $444 \mathrm{pp}$.

YEH F.C., YANG R.C., BOYLE T.B.J., YE Z.H., MAO J.X. 1997. Popgene, the user-friendly shareware for population genetic analysis. Molecular Biology and Biotechnology Center, University of Alberta, Edmonton, Alberta, Canada (http://www.ualberta.ca/ fyeh/index.htm).
ZAJĄC A., ZAJĄC M. (eds). 2001. Atlas rozmieszczenia roślin naczyniowych w Polsce. Distribution Atlas of Vascular Plants in Poland. Edited by Laboratory of Computer Chorology, Institute of Botany, Jagiellonian University, Kraków, 714 pp. (in Polish)

ZAPAŁOWICZ H. 1906. Krytyczny przegląd roślinności Galicyi [Conspectus florae Galiciae criticus]. Nakładem Akademii Umiejętności, Kraków, Vol. 1. 296 pp. (in Polish and Latin) 